\title{
PERTUMBUHAN IKAN NILA (OREOCHROMIS NILOTICUS) YANG DIBERI PAKAN MENGANDUNG IKAN ASIN BAWAH STANDAR (IABS) DENGAN KESEGARAN BERBEDA
}

\section{THE GROWTH OF NILE TILAPIA (OREOCHROMIS NILOTICUS) FED THE LOWEST STANDARD OF SALTED FISH ON VARIETY OF FRESHNESS}

\author{
Fitri Ariantini ${ }^{1 a}$, Rosmawati ${ }^{1}$, Titin Kurniasih ${ }^{2}$ \\ ${ }^{1}$ Jurusan Perikanan, Fakultas Pertanian, Universitas Djuanda Bogor \\ J1. Tol Ciawi No.1, Kotak Pos 35, Kode Pos 16720 \\ ${ }^{2}$ Balai Penelitian dan Pengembangan Budidaya Air Tawar, Sempur Bogor \\ Korespondensi: Rosmawati, Email: rosmawati@unida.ac.id \\ (Diterima: 29-09-2015, Ditelaah: 04-10-2015, Disetujui: 09-10-2015)
}

\begin{abstract}
This research is aimed to know the effect of freshness level of the lowest standard of salted fish in food formulation against the growth of nile tilapia compared with food formulation standar (food based on fishmeal). The treatments are food based on fishmeal without the lowest standard of salted fish, food cantains the lowest standard of fresh salted fish, and food cantains of the lowest standard of less fresh salted fish. Specific growth rate, food consumption, food efficiency, survival rate and water quality had been evaluated. The results of research showed there was a significantly different between treatments for specific growth rate and food efficiency, but there was not a significantly different for food consumption, survival rate and water quality. The best of spesific growth rate and food efficiency get from treatment B with the average of $2.37 \%$ and $45.19 \%$. The freshness level of salted fish material was a significantly different for growth and food efficiency of Nile tilapia, but was not a significantly different for survival rate of Nile tilapia.

Key words: the lowest standard of salt fish, freshness, Nile tilapia, growth, food efficiency
\end{abstract}

\begin{abstract}
ABSTRAK
Penelitian ini bertujuan untuk mengetahui pengaruh tingkat kesegaran IABS dalam formulasi pakan terhadap pertumbuhan ikan nila dibandingkan dengan formulasi pakan standar (pakan berbasis tepung ikan). Rancangan percobaan yang digunakan adalah Rancangan Acak Lengkap (RAL) dengan 3 perlakuan dan 3 ulangan. Ikan nila yang digunakan memiliki berat rata-rata 5,23 $\pm 0,02$ gram dengan padat tebar 20 ekor per akuarium. Perlakuan pakan yang diberikan yakni pakan berbasis tepung ikan tanpa IABS, pakan mengandung IABS segar dan pakan mengandung IABS kurang segar. Parameter yang diukur adalah laju pertumbuhan spesifik (LPS), jumlah konsumsi pakan (JKP), efisiensi pakan (EP), tingkat kelangsungan hidup (SR) dan parameter kualitas air. Hasil penelitian menunjukkan bahwa ada perbedaan nyata $(\mathrm{P}<0,05)$ di antara perlakuan untuk parameter LPS dan EP, tetapi tidak berbeda nyata $(\mathrm{P}>0,05)$ untuk parameter JKP, SR dan kualitas air. Tingkat kesegaran bahan ikan asin sangat berpengaruh terhadap pertumbuhan dan efisiensi pakan untuk ikan nila, tetapi tidak untuk kelangsungan hidup ikan nila (Oreochromis niloticus). Pemberian IABS segar menghasilkan pertumbuhan dan efisiensi pakan yang sama baiknya dengan pakan standar dan lebih baik daripada pemberian IABS kurang segar.

Kata kunci : IABS, protein, ika nila, pertumbuhan, tepung ikan.
\end{abstract}


Fitri Ariantini et.al. 2015. Pertumbuhan Ikan Nila (Oreochromis Niloticus) yang Diber Pakan Mengandung Ikan Asin Bawah Standar (IABS) Dengan Kesegeran Berbeda. Jurnal Mina Sains 1(2) : 79-85.

\section{PENDAHULUAN}

Sumber protein pakan yang berkualitas tinggi seperti tepung ikan dan tepung bungkil kedelai semakin terbatas, dikarenakan stok ikan rucah di laut sebagai bahan baku bagi produksi tepung ikan semakin menipis sehingga harganya meningkat, dan harga kedelai yang semakin tidak terjangkau. Konsekuensinya, upaya pencarian sumber bahan baku alternatif yang memiliki nilai nutrisi tinggi, ketersediaannya melimpah dan harganya ekonomis merupakan fokus perhatian utama bagi pembudidaya dan ahli nutrisi ikan.

Ikan asin yang kualitasnya di bawah standar (IABS) adalah salah satu sumber protein yang berpotensi bagi pakan ikan dan ternak. Jumlahnya melimpah, harganya sangat murah (Rp 1.500,- per kilogram) dan kontinyuitasnya terjamin. IABS memiliki kadar protein cukup tinggi yaitu sekitar 30-50\%. Penggunaan IABS bersamaan dengan beberapa bahan lain yang bersifat saling melengkapi akan dapat meningkatkan kualitas nutrisi dan performa pertumbuhan ikan.

Terkait dengan kondisi kadar garam yang tinggi pada IABS, Kurniasih dan Melati (2012) menguji perlakuan IABS yang direndam (desalinasi) dengan yang tidak direndam. Hasilnya ternyata tidak ada perbedaan nyata di antara kedua perlakuan tersebut terhadap pertumbuhan dan efisiensi pakan ikan nila. Masalah yang muncul terkait dengan bahan IABS biasanya berhubungan dengan tingkat kesegarannya. IABS yang tidak segar akan mengandung amina biogenik dan kontaminasi mikroba dalam kadar tinggi serta kehilangan sejumlah asam amino tertentu.

Terlepas dari permasalahan yang ada padanya, IABS merupakan sumber protein alternatif yang potensial. Kadar proteinnya yang cukup tinggi dapat diharapkan mengurangi ketergantungan formulasi pakan ikan terhadap tepung ikan. Berdasarkan permasalahan diatas maka perlu dilakukan penelitian tentang kesegaran ikan asin bawah IABS terhadap pertumbuhan ikan nila (Oreochromis niloticus).

\section{MATERI DAN METODE}

Pakan yang digunakan dalam penelitian ini adalah pakan buatan (formulasi) selain tepung ikan dan ikan asin juga digunakan bahan lain yaitu tepung bungkil kedelai, tapioka, dedak, 
polard, minyak ikan, minyak jagung, premix dan CMC (carboksi methyl celulosa) dengan komposisi bahan pakan dan hasil analisis proksimat pakan percobaan (Tabel 1). Pakan terdiri atas tiga jenis yakni : pakan tidak mengandung IABS, pakan yang mengandung IABS segar, pakan yang mengandung IABS kurang segar. bahan tersebut dicampurkan menjadi satu, kemudian dimasukan pada pencetak pellet setelah itu dijemur hingga kering mengunakan bantuan sinar matahari
Ikan yang digunakan dalam penelitian adalah ikan nila (Oreochromis niloticus) berat rata-rata 5,23 $\pm 0,02$ gram dan padat penebaran 20 ekor per akuarium yang berukuran 50x60x40 $\mathrm{cm}^{3}$ sebanyak 9 buah diisi air sebanyak 90 liter. Ikan diberi pakan setiap pukul 08.00, 11.00, 13.00, 15.00 WIB sebanyak 7\% dari bobot biomassa ikan nila per akuarium per hari. Rancangan dalam percobaan ini adalah Rancangan Acak Lengkap (RAL) dengan 3 perlakuan dan 3 ulangan.

Tabel 1. Komposisi paka percobaan dan proksimat

\begin{tabular}{crrr}
\hline Bahan Baku & \multicolumn{3}{c}{ Persentase (\% bobot kering) } \\
\cline { 2 - 4 } & \multicolumn{1}{c}{ Kontrol } & Pakan B & Pakan C \\
\hline Tepung Ikan & 20,0 & 8,5 & 8,5 \\
Ikan asin BS & 0,0 & 20,0 & 14,5 \\
Tp Bungkil Kedelai & 26,0 & 26,0 & 26,0 \\
Tapioka & 8,0 & 0,0 & 5,5 \\
Dedak & 14,0 & 13,5 & 13,5 \\
Polard & 25,0 & 25,0 & 25,0 \\
Minyak ikan & 1,5 & 1,5 & 1,5 \\
Minyak jagung & 1,5 & 1,5 & 1,5 \\
Premix & 2,0 & 2,0 & 2,0 \\
CMC & 2,0 & 2,0 & 2,0 \\
\hline TOTAL & 100,0 & 100,0 & 100,0 \\
\hline Komposisi Proksimat Pakan Uji & \\
\hline Protein & 28,31 & 28,21 & 28,21 \\
Lemak & 7,70 & 7,30 & 7,50 \\
Abu & 11,04 & 11,33 & 11,21 \\
Serat Kasar & 3,39 & 3,52 & 3,45 \\
BETN & 49,45 & 49,64 & 49,21 \\
Energi Tercerna & 285,08 & 281,97 & 282,51 \\
Rasio Energi/Protein & 10,07 & 10,00 & 10,01
\end{tabular}

Perlakuan pakan yang diberikan: pakan ikan tanpa IABS, pakan yang mengandung IABS segar, pakan yang mengandung IABS kurang segar.
Percobaan pertumbuhan ini dilakukan selama 53 hari. Penggantian air di tandon filter dilakukan setiap 1 minggu sekali, dan penyiponan kotoran dilakukan setiap 
hari. Sampling pertumbuhan ikan dilakukan selama 15 hari sekali.

Parameter yag diukur yakni: laju pertumbuhan spesifik (LPS), jumlah konsumsi pakan (JKP), efisiensi pakan (EP), tingkat kelangsungan hidup (SR), kualitas air.

\begin{tabular}{cccc}
\hline \multirow{2}{*}{ Ulangan } & \multicolumn{3}{c}{ Perlakuan } \\
\cline { 2 - 4 } & $\mathrm{A}$ & \multicolumn{1}{c}{$\mathrm{B}$} & $\mathrm{C}$ \\
\hline 1 & 2.07 & 2.20 & 2.16 \\
2 & 2.38 & 2.42 & 2.01 \\
3 & 2.34 & 2.5 & 2.00 \\
\hline Rata-rata & $2.26^{\mathrm{ab}}$ & $2.37^{\mathrm{b}}$ & $2.06^{\mathrm{a}}$ \\
\hline
\end{tabular}

Keterangan : Superskrip huruf yang sama menunjukkan tidak berbeda nyata $(\mathrm{P}>0,05)$.

Laju pertumbuhan spesifik

\section{HASIL DAN PEMBAHASAN}

\section{Laju Pertumbuhan Spesifik (\%)}

Hasil uji analisis ragam terhadap parameter LPS menunjukkan ada perbedaan nyata $(\mathrm{P}<0,05)$ antar perlakuan (tabel 2). Uji lanjut Duncan menunjukkan bahwa pakan B (IABS segar) sama baiknya dengan pakan A (kontrol), tetapi lebih baik dari pada pakan C (IABS kurang segar).

Tabel 2. Laju pertumbuhan ikan nila selama penelitian

Grafik Laju Pertumbuhan Spesifik

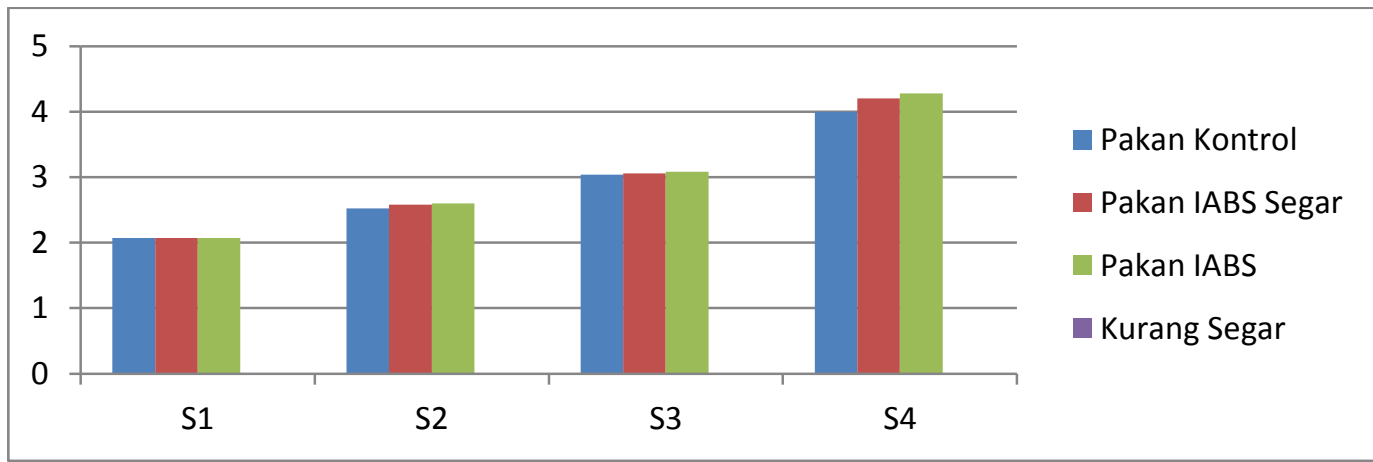

Gram $\quad \mathrm{S}=$ Sampling

Gambar 1. Grafik LPS ikan ikan nila

(Oreochromis niloticus)

Menurut Askar dan Treptow dalam tepung ikan yang terbuat dari ikan (1986), beberapa penelitian telah kurang segar, yang menyebabkan bertujuan untuk mengetahui faktor- faktor penurunan pertumbuhan ikan. Pada 
perlakuan menggunakan IABS segar dengan perlakuan hanya menggunakan tepung ikan menunjukkan tingkat pertumbuhan yang sama, bisa dikatakan bahwa IABS yang masih segar ini bisa menggantikan tepung ikan lokal yang harganya mahal.

\section{Jumlah Konsumsi Pakan (gram)}

Jumlah konsumsi pakan pada saat penelitian (Tabel 3) menunjukkan bahwa pakan yang diberikan pada ikan nila (Oreochromis niloticus) tidak berbeda nyata antar perlakuan $(\mathrm{P}<0,05)$.

Tabel 3. Jumlah konsumsi pakan (JKP)

\begin{tabular}{cccc}
\hline Ulangan & \multicolumn{3}{c}{ Perlakuan } \\
\cline { 2 - 4 } & $\mathrm{A}$ & $\mathrm{B}$ & $\mathrm{C}$ \\
\hline 1 & 525.80 & 516.84 & 570.31 \\
2 & 577.04 & 558.02 & 546.02 \\
3 & 565.31 & 604.22 & 538.79 \\
\hline Rata-rata & 556.05 & 559.69 & 551.71 \\
\hline
\end{tabular}

Formulasi pakan harus dilengkapi dengan perangsang yang disebut atraktan untuk membuat asupan pakan ikan lebih efisien (Hertrampf dan Pascual, 2000). Pada penelitian ini atraktan yang diberikan sama pada setiap perlakuan yaitu minyak ikan.

\section{Efisiensi Pakan (\%)}

Hasil analisis ragam menunjukkan bahwa ada perbedaan nyata antar perlakuan $(\mathrm{P}<0,05)$, ini menunjukkan pemberian IABS dengan kesegaran yang berbeda pada pakan menghasilkan efisiensi pakan yang berbeda.

Tabel 4. Efisiensi Pakan ikan nila (\%)

\begin{tabular}{cccc}
\hline \multirow{2}{*}{ Ulangan } & \multicolumn{3}{c}{ Perlakuan } \\
\cline { 2 - 4 } & $\mathrm{A}$ & $\mathrm{B}$ & $\mathrm{C}$ \\
\hline 1 & 40.02 & 41.72 & 39.51 \\
2 & 46.08 & 45.97 & 36.21 \\
3 & 45.51 & 47.87 & 36.80 \\
\hline Rata-rata & $43.87^{\mathrm{b}}$ & $45.19^{\mathrm{b}}$ & $37.51^{\mathrm{a}}$ \\
\hline
\end{tabular}

Keterangan : Superskrip huruf yang sama menunjukkan tidak berbeda nyata $(\mathrm{P}>0,05)$.

Hasil penelitian menunjukkan pemberian pakan dengan menggunakan IABS segar menghasilkan efisiensi tertinggi yaitu 45,19\%, sedangkan pakan yang diberi IABS kurang segar menghasilkan nilai efisiensi terendah yaitu 37,51\%. Uji lanjut Duncan menunjukan bahwa efisiensi pakan perlakuan $\mathrm{B}$ berbeda nyata dengan perlakuan $\mathrm{C}$, namun perlakuan $\mathrm{B}$ tidak berbeda nyata dengan perlakuan A.

\section{Tingkat Kelangsungan Hidup (\%)}

Derajat kelangsungan hidup ikan nila selama pemeliharaan pada perlakuan pemberian tanpa IABS100\%, menggunakan IABS segar 97\%, dan yang menggunakan IABS kurang segar 100\% (Gambar 2). 
Grafik Jumlah Komsumsi Pakan

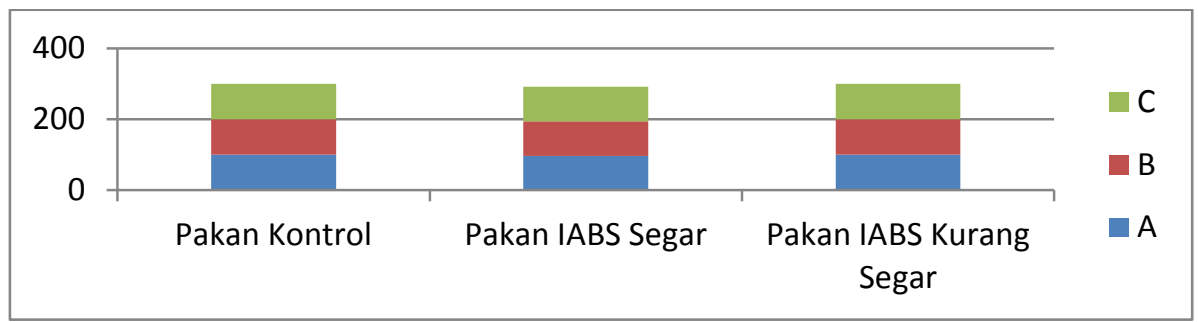

Perlakuan

Gambar 2. Grafik kelangsungan hidup ikan nila (Oreochromis niloticus)

Dari hasil analisis sidik ragam didapatkan bahwa perlakuan pemberian IABS tidak memberikan pengaruh yang nyata terhadap kelangsungan hidup ikan nila $(\mathrm{P}>0,05)$, karena energi terhadap ikan yang berasal dari pakan yang diberikan dari masing-masing perlakuan sudah tercukupi (Tabel 5).

Tabel 5. Tingkat Kelangsungan Hidup $(\mathrm{SR})$

\begin{tabular}{cccc}
\hline \multirow{2}{*}{ Ulangan } & \multicolumn{3}{c}{ Perlakuan } \\
\cline { 2 - 4 } & $\mathrm{A}$ & $\mathrm{B}$ & $\mathrm{C}$ \\
\hline 1 & 100 & 95 & 100 \\
2 & 100 & 95 & 100 \\
3 & 100 & 100 & 100 \\
\hline Rata-rata & 100 & 97 & 100 \\
\hline
\end{tabular}

Meskipun kelangsungan hidup di antara ketiga perlakuan tidak berbeda nyata, tetapi sangat mungkin akan didapatkan perbedaan secara histologi seluler di antara kedua perlakuan. Menurut Opstvedt et al. (2000), perlakuan pemberian pakan yang mengandung bahan baku ikan segar dan tidak segar akan memberikan efek perbedaan pada histologi sel usus. Ikan yang mengkonsumsi pakan yang mengandung bahan ikan yang tidak segar.

Tingkat kelangsungan hidup sama, menunjukkan juga bahwa semua pakan sudah mencukupi kebutuhannya untuk kelangsungan hidup bahkan untuk pertumbuhan, selain itu kualitas air masih bagus dan mendukung untuk ikan hidup dengan pertumbuhan yang baik.

\section{Kualitas Air}

Kisaran kualitas air selama pemeli-haraan 53 hari yaitu suhu 27$28^{0} \mathrm{C}, \quad \mathrm{pH}$ 6,5-6,9, oksigen terlarut (DO) 4,45-5,0 ppm (Tabel 6). Nilai yang didapat dari hasil pengukuran menunjukkan bahwa parameter fisikakimia air dalam kondisi yang baik untuk pemeliharaan ikan nila.

Tabel 6. Rata-rata hasil pengamatan kualitas air selama pemeliharaan

\begin{tabular}{cccl}
\hline Parameter & \multicolumn{3}{c}{ Perlakuan } \\
\cline { 2 - 4 } Kualitas air & $\mathrm{A}$ & $\mathrm{B}$ & \multicolumn{1}{c}{$\mathrm{C}$} \\
\hline Suhu ${ }^{0} \mathrm{C}$ & $27-28$ & $27-28$ & $27-28$ \\
$\mathrm{DO}(\mathrm{ppm})$ & $4,45-5,0$ & $4,46-5,0$ & $4,45-5,0$ \\
\hline $\mathrm{pH}$ & $6,5-6,9$ & $6,5-6,9$ & $6,5-6,9$ \\
\hline
\end{tabular}


Nilai yang didapat dari hasil pengukuran menunjukan bahwa parameter fisika-kimia air dalam kondisi yang baik dan cocok untuk pemeliharaan ikan nila. Suhu pada penelitian berkisar antara $27^{\circ} \mathrm{C}$ sampai $28^{0} \mathrm{C}$. fluktuasi pada saat penelitian sangat kecil antara $1-2^{0} \mathrm{C}$, hal ini dikarenakan ruangan penelitian tertutup sehingga suhu dapat lebih stabil. Selama masa pemeliharaan nilai $\mathrm{pH}$ yang diperoleh relatif stabil berkisar antara 6,5-6,9, hal ini diduga karena adanya arang pada sistem resirkulasi yang dapat berfungsi sebagai penyangga $\mathrm{pH}$ air (pH buffer). Menurut Landau (1992), arang dapat membantu mempertahankan nilai $\mathrm{pH}$ air karena tersusun atas kalsium kerbonat. Pada peneltian ini digunakaan sistem resirkulasi, sistem resirkulasi pada intinya terjadi dua proses yaitu, produksi limbah dan pengelolaan limbah. Prinsip kerja resirkulasi adalah memindahkan limbah dari wadah budidaya dan mengembalikan media ke dalam wadah dengan mutu mendekati semula walaupun tidak seluruh limbah dapat dihilangkan dari media.

\section{KESIMPULAN}

Tingkat kesegaran bahan ikan asin sangat berpengaruh terhadap pertumbuhan dan efisiensi pakan untuk ikan nila, tetapi tidak untuk kelangsungan hidup ikan nila (Oreochromis niloticus). Pemberian IABS segar menghasilkan pertumbuh-an dan efisiensi pakan sama baiknya dengan pakan kontrol, tetapi secara signifikan lebih baik dari pemberian IABS kurang segar.

\section{DAFTAR PUSTAKA}

Askar A, Treptow H. 1986. Biogene Amine in Lebensmitteln. Eugen Ulmer and Co., Stuttgart, Germany, 197 pp

Kurniasih T, Melati I. 2012. Efektivitas metode desalinasi terhadap kualitas nutrisi ikan asin bawah standar. Laporan teknis hasil penelitian tahun anggaran 2012. Balai Riset Perikanan Budidaya Air Tawar. Bogor.

Hetrampf JW, Pascual FP. 2000.

Handbook on Ingredients for Aquaculture Feeds. Kluwer Acadmic Publishers, London.

Landau M. 1992. Introduction to Aquaculture. Jhon Whiley \& Sons., Inc., New York

Opstvedt J, Mundheim H, Nygard E, Aese H, Pike HI. 2000. Reduced growth and feed consumption of Atlantic salmon (Salmo salar L.) fed fish meal made from stale fish is not due to increased content of biogenic amines. Aquaculture 188: 232-337. 